\title{
REVIEW
}

\section{PASSENGER SAFETY ON WHALE-WATCHING VESSELS IN AUSTRALIA}

\author{
JEFF WILKS,* (D) MICHAEL LÜCK, $†$ (1) AND MARK ORAMS $\$ \S$ \\ * Southern Cross University, Southern Cross Drive, Bilinga, Queensland, Australia \\ $\dagger$ School of Hospitality and Tourism, Auckland University of Technology, Auckland, New Zealand \\ \$USC Business School and Sustainability Research Centre, University of the Sunshine Coast, \\ Queensland, Australia \\ $\S$ School of Sport and Recreation, Auckland University of Technology, Auckland, New Zealand
}

\begin{abstract}
To date, the focus of research into risks and safety in whale watching has tended to be on the safety of the whales (or dolphins/porpoises). This article explores the issue from the human side of the interaction and considers boat-based whale-watching passenger safety by reviewing evidence from available legal case records and legislation in Australia to better understand the risks and injuries that can occur to people in these marine wildlife tourism scenarios. A review of two legal cases and observations from media reports of whale-watching incidents in other jurisdictions revealed that waves and associated violent vessel movement are responsible for serious injuries to passengers. Where there was a failure to keep a proper lookout for waves and safely adapt to changing sea conditions operators have been found negligent. Legal challenges have also been successful in cases involving inaccurate and misleading promotion and communication about the nature of the tour and associated risks, and where passengers had not received adequate safety briefings. Furthermore, signed waivers that sought to protect the tour operator from responsibilities for injuries sustained aboard were not sufficient to absolve operators from liability. Given the different cultures, languages, and physical capabilities of a diverse range of international tourists interested in whale watching it is recommended that promotional materials, safety briefings, and safety communications (such as warning signs) be communicated by widely used and understood symbols and in multiple languages. In addition, some screening of passengers to ascertain preexisting medical conditions and to assess their ability to participate in the voyage safely, and with understanding of safety instructions, should be undertaken prior to a vessel leaving the dock. Templates to assist operators with their responsibilities are now available from the Australian Maritime Safety Authority.
\end{abstract}

Key words: Whale watching; Safety; Accidents; Injuries; Lawsuits; Australia

Address correspondence to Jeff Wilks, Southern Cross University, Southern Cross Drive, Bilinga, Queensland 4225, Australia. E-mail: jeff.wilks@scu.edu.au 


\section{Introduction}

In the past 30 years there has been an increasing fascination with nature and, in particular, viewing and interacting with wild animals in their natural habitat (Newsome, Dowling, \& Moore, 2005). Examples include safari viewing for the "Big 5 " in South Africa (the lion, leopard, rhinoceros, elephant, and Cape buffalo) (Lindsey, Alexander, Mills, Romañach, \& Woodroffe, 2007), watching and swimming with whales and dolphins (Higham, Bejder, \& Williams, 2014), and avitourism or birdwatching (Steven, Morrison, \& Castley, 2015). More recently the "Big 5" has been expanded to the "Big 7" in South Africa to include the marine species of southern right whales and great white sharks (Brand South Africa, 2009), thereby promoting wildlife tourism opportunities in both the terrestrial and marine environments.

Within the marine environment close encounters with large and charismatic animals such as whales, dolphins, seals, dugongs, sea otters, sea turtles, penguins, albatross, polar bears, sharks, and rays have become increasingly popular (Higham \& Lück, 2007). This has resulted in a commensurate increase in a variety of means to engage with these species including via a range of different types of boats and cruise ships, but also via scuba diving, snorkeling, kayaks, stand-up paddle boards, and both onshore and underwater observation points, as well as by aircraft (both fixed wing and rotary) (Higham \& Lück, 2007).

As a consequence of concerns over the potential negative effects of such activities a range of government regulations and industry codes of practice have been developed - for example, the Australian National Guidelines for Whale and Dolphin Watching (Department of Environment and Energy, 2017). In addition, a number of nongovernmental and formal international organizations (such as the International Whaling Commission) have developed guidelines and initiatives in an attempt to reduce the negative effects of this tourism growth and contribute to its long-term sustainability (Carlson, Rose, Kato, $\&$ Williams, 2014). These management approaches have tended to focus on controlling the activities of whale-watch operators and whale watchers to minimize the potential of negative effects on the whales. This focus has been driven by the growing body of research which shows that these activities are not benign and the increasing evidence of disturbance to natural behavior patterns that could be harmful to the targeted species (Orams, Forestell, \& Spring, 2014; Parsons, 2012).

The focus on the effects of whale watching on the whales has been accompanied by a range of social science research that has concentrated on the effects on the tourists. In particular, scholars have examined the economic effects of the development of the industry (e.g., Hoyt, 2001; O'Connor, Campbell, Cortez, \& Knowles, 2009; Wilson \& Tisdell, 2003) and issues such as the effectiveness of educational programs delivered by operators as part of the tourism experience (e.g., Anderson \& Miller, 2006; Finkler \& Higham, 2004; Lück, 2003, 2015; Zeppel \& Muloin, 2008).

There has also been ongoing interest in tourist satisfaction with the whale-watching experience. Bentz, Lopes, Calado, and Dearden (2016) reported that seeing one whale, seeing lots of whales, the cost of the trip, and the boat type were the most influential factors contributing to satisfaction among whale watchers in the Azores.

Orams (2000) found that whale watching is not simply about getting close to whales. Other variables such as the number of whales and their behavior, numbers of fellow passengers, cruise duration, boat construction, and sea sickness all influenced satisfaction.

However, less attention has been given to the safety of passengers aboard whale-watching vessels. This is surprising because the risks involved with maritime operations, especially in the context of vessel-based marine recreation and tourism, are well understood and there are numerous examples of injuries and fatalities associated with marine vessel-based tourism. Examples include passenger ferries (Talley, 2002), cruise ships (Lois, Wang, Wall, \& Ruxton, 2004), recreational fishing (Jasper, Stewart, \& Knight, 2017), recreational boating (European Child Safety Alliance, 2007), scuba diving (Wilks, 2000, 2007; Wilks \& Davis, 2000), and personal watercraft (Al-Thani, El-Menyar, Mekkodathil, \& Abdfelrahman, 2017; Wilks, 2010, 2012). It is possible that the issue of passenger safety aboard whale-watching vessels has not attracted the attention of researchers and authors because this area of responsibility falls largely within maritime 


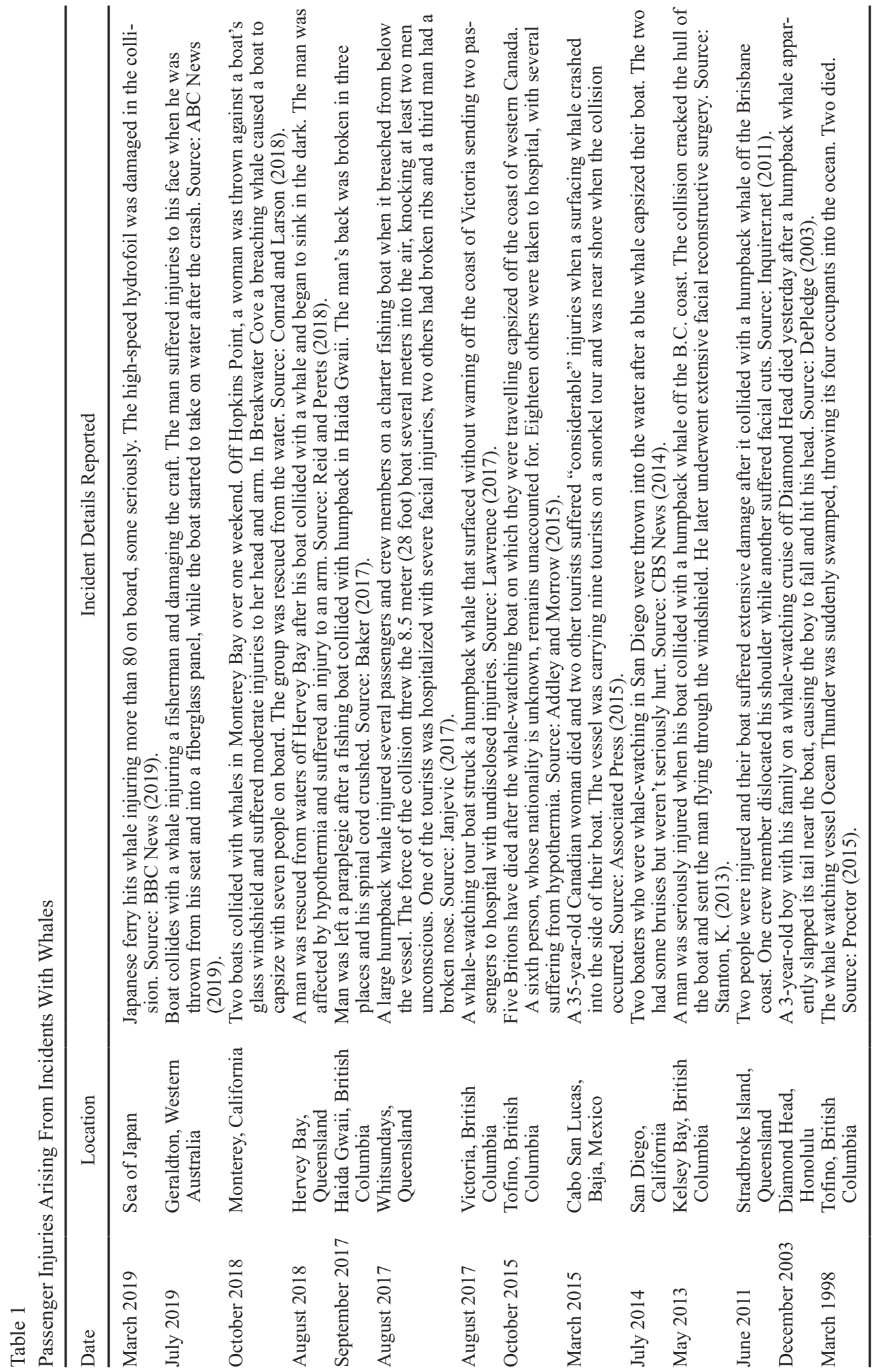


transport regulations rather than whale-watching regulatory regimes per se.

However, there are a number of cases of accidents and fatalities associated with whale-watching activities reported in the media. Examples include the death of a 3-year-old boy who hit his head on a handrail during a whale-watching trip off Diamond Head, Hawaii in 2003 (Lum \& Gordon, 2003); two fatalities on a whale-watching boat off Tofino, British Columbia in 1998 (Proctor, 2015), and another incident in 2015 also off Tofino, British Columbia where the whale-watching vessel Leviathan II capsized and six passengers drowned (Givetash, 2018).

It is important to distinguish between passenger and crew injuries that occur during whale-watching activities as opposed to other incidents where a vessel collides with a whale in general ocean traffic. The latter is more commonly reported in the media. Table 1 presents the results of a media search on passenger injuries arising from incidents with whales.

While there are now clear guidelines in place about approach distances for vessels (Department of Environment and Energy, 2017), the fact that whales surface unexpectedly is a major factor in collisions. Interestingly, analysis of data from the International Whaling Commission shows that whales are more likely to be hit by whale-watching boats than any other identified vessel type (Farrell \& Evershed, 2014).

The issue of safety for vessel-based whale watching is therefore topical and important, particularly given the rapid growth and global spread of these activities. This article seeks to address this issue by exploring the available records of legal actions taken in Australia as a consequence of accidents aboard whale-watching vessels. The review of case law offered here provides an opportunity to examine key issues affecting such negative outcomes. This is an approach adopted in tourism law where there is often little publicly available litigation (see Wilks, 2008). Through this review important lessons for management can be gained that, if implemented, can reduce the potential of further serious accidents in this marine tourism context.

\section{Whale Watching}

Whale watching is defined by the International Whaling Commission (IWC) to include all cetaceans - whales, dolphins, and porpoises - and the variety of tourism activities that are based upon these species. This includes more than just "watching" whales but tourism activities such as photography/videography (above and below water and using drones), swimming/snorkeling and diving, feeding/provisioning, and other means of encountering whales, dolphins, and porpoises in the wild (thus it excludes cetaceans held in captive settings such as oceanariums/aquariums) (IWC, 2019).

According to the IWC the goal of sustainable whale watching is that it is conducted in harmony with healthy cetacean populations in a healthy environment. To this end the IWC works with scientists, governments, NGOs, and the whale-watching industry to assess threats, identify and share best practice, and support responsible, sustainable whale watching (IWC, 2019).

Whale watching has become a significant global industry occurring in 119 countries and territories (O’Connor et al., 2009), generating an estimated US $\$ 2.5$ billion annually and creating nearly 19,000 jobs (Cisneros-Montemayor, Sumaila, Kaschner, \& Pauly, 2010; Hoyt, 2001; Knowles \& Campbell, 2011). Its growth has been spectacular. The world's first commercial whale watching began in the second half of the 20th century and it has spread and diversified to include a wide range of cetacean species and using a range of opportunities to encounter and interact with cetaceans.

In his benchmark review, Hoyt (2001) noted that the most common form of whale watching is boat based ( $72 \%$ of all whale watching) and in most coastal and maritime countries whale watching is an important activity for international tourists. Media reports confirm this. For example, Cooper (2016) noted that whale watching draws more than half a million foreign tourists to Queensland each year. Among the major growth markets are Chinese tourists for whom nature-based, and in particular wildlife, experiences are a very high priority (ORC International, 2014). Tourism \& Events Queensland (2018) recorded that of the 503,000 Chinese visitors to the State $41 \%$ each seek marine life and Great Barrier Reef experiences. Indeed, those Chinese visitors surveyed whose nature-based experience was better than expected were more likely to be highly satisfied with their holidays overall. According to a recent Nielsen (2017) report, the 
two most important factors Chinese tourists consider when choosing an overseas travel destination are (1) beauty and uniqueness of tourist attractions and (2) safety.

\section{Whale-Watching Regulations}

From a review of whale-watching guidelines and regulations around the world Carlson (2012) recommended that any commercial cetacean-watching activity should only be carried out under a permit granted by the appropriate authority. The suggested criteria for permits included, inter alia: that the vessel used meets appropriate national safety standards; that the vessel used be insured for the passengers that it carries; and that the vessel be judged appropriate for whale watching.

In Australia, the National Guidelines for Whale and Dolphin Watching (Department of Environment and Energy, 2017) address the various ways people watch whales and dolphins, including from a vessel, an aircraft, while swimming, and from on-shore. The Guidelines note that certain vessel types, due to the noise they generate or the speed at which they travel, may lead to greater negative impacts. As a result, some vessels are prohibited from engaging in whale and dolphin watching. These are referred to as "prohibited vessels" and include all personal motorized watercraft (e.g., jet skis and underwater scooters), parasails, remotely operated craft, wing-in-ground effect craft, and hovercraft. In contrast, "allowable vessels" that may engage in whale and dolphin watching include all other motorized, paddle, and/or sail craft (e.g., motorboats, yachts, kayaks, canoes, surf skis, and inflatable craft). While the Guidelines provide detailed responsibilities about safety and protection for whales and dolphins, the safety of passengers is only considered in the context of protecting the animals. For example, "for your safety, it is important that you do not approach a disturbed or injured animal and that you stay outside the caution zones outlined in the national guidelines if in a vessel or as a swimmer" (p. 6).

To provide commercial whale-watching services in Queensland, for example, the tourist operator is required to hold a Commercial Wildlife License (Wildlife Interaction) from the Queensland Government Department of Environment and Science
(2018) and a permit to carry out activities in Marine Parks (Queensland Marine Parks, 2017). The Wildlife License includes submission of an Interaction Plan for the wildlife they intend to engage with and compliance with the plan. A template is available to assist with developing the Interaction Plan and it includes several opportunities to consider safety issues.

Under Description of Activity:

\begin{abstract}
4.2 Do you have any public liability insurance that protects you in the event that people are injured while participating in the wildlife interaction you propose? If yes, please attach details of the insurance policy.
\end{abstract}

4.3 Interacting with wildlife can be dangerous, both to wildlife and people participating in the activity. There may be certain things you could do to minimise the likelihood of harm occurring. How do you intend to manage the activity to ensure risks to wildlife and people are minimised?

Unfortunately, like other areas of tourism, the issues around human safety are often only addressed after a serious problem occurs. For example, following the "swamping" in a large swell of the whalewatching boat Ocean Thunder off Tofino, British Columbia in March 1998, in which a crew member and a passenger died, the Transportation Safety Board of Canada (1998) investigation made a series of recommendations around predeparture safety briefings, communication and personal flotation devices (PFDs). Years later the same issues were identified by the coroner in the case of the sinking of the whale-watching vessel Leviathan II in the same general area in October 2015 (Cote, 2017).

\section{Cases of Injuries Related to Whale Watching in Australia}

Overall, there is little legal information publicly available on injuries to passengers during whalewatching excursions. One reason for this is that plaintiff cases seldom make it to court, being settled early with a confidentiality clause preventing the parties from discussing the matter. This is generally the case in all areas of tourist injury, where an industry selling "dreams" does not want negative media exposure about customer mishaps (Wilks \& Page, 2003). 
A search of Australian legal databases (Lexis Advance, Westlaw $\mathrm{AU}, \mathrm{CCH}$ Intelli Connect, AUSTLII, JADE, Informit, and LexisNexis for both reported and unreported cases) and the popular media in Australia revealed only two reported legal cases of injuries to passengers while whale or dolphin watching. This represents a serious underreporting of such situations. The search also identified two other legal cases of adventure boat injuries (Rohra v Ox Two Pty Ltd, 2016; Talwar v Ox Two Pty Ltd, 2017) that highlighted key issues to be considered for whale watching, as well as media reports of collisions between whales and fishing vessels (ABC News, 2019; Janjevic, 2017) in Australian waters. While there are only two legal cases to report, nevertheless these cases provide important insights into the risks to human safety in such scenarios. Each of these cases is reviewed below.

\section{Cases}

In Lormine Pty Ltd \& Anor v Xuereb [2006] NSWCA 200 the plaintiff, Juliet Xuereb, was injured during a dolphin-watching cruise. According to court documents she had been encouraged to book the cruise after reading the ship owner's brochure indicating "calm ocean water ... suitable for people of all ages." On arrival at the dock on the day of the trip, passengers were shown a form with printing at the top and blank spaces below that was required to be ticked for attendance and signed. Advised that the form was for head count purposes, Ms. Xuereb ticked herself off and the members of her party, initialing for each of them in the space provided. The unread printed portion of the form purported to waive the ship owner's liability in respect of "SCUBA diving and/or snorkeling activities, as well as the use of any facilities and the use of the equipment" of the Dive Centre. Once out to sea, the captain invited willing passengers to travel on the foredeck by sitting on the bow, holding themselves secure by handling the rails. Having taken up the offer, Ms. Xuereb was subsequently swept astern by the force of a rogue wave that crashed over the bow, causing her to sustain severe injuries. The trial judge found that the captain had failed to keep a proper lookout for the wave, meaning he did not have sufficient time to turn the boat directly into the path of the wave.
On appeal a few important points were clarified. First, tourist operators should be careful with the statements made in their brochures. The court held that "the applicant's brochure admitted of the gentle activity in which the respondent had been invited to engage. There was nothing to suggest getting swamped by a wave was one of the expected thrills of the cruise." Second, the risk in this case was not an "obvious risk" as defined by legislation. Indeed, it could have been avoided by the exercise of reasonable care and skill. The court held that "it had in fact been want of care and skill that caused the injuries." Lastly, to be effective a Release of Liability or Waiver of Claims form needs to be clearly worded and drawn to the attention of the customer(s) ideally at the time of booking the excursion.

The second available case also involved waves and associated violent vessel movement. In Bell v Raymond John Fowler t/a Port Macquarie Cruise Adventures, an unreported 2017 case in the Newcastle District Court, the news story was widely reported as follows (Tripleem News, 2018):

Hamlyn Terrace Woman Compensated For Whale Watching Injury. Broke Her Back

A Hamlyn Terrace woman has won a six figure settlement, despite signing a waiver before a whale watching trip turned into a nightmare with lifelong consequences.

Linda Bell was holidaying with her husband on the state's North Coast in October 2015 when they decided to take the fateful journey.

"He was going too fast for the conditions," Ms Bell explains. "I ended up going up really high on the crest of a wave, came back down really hard onto the seat and broke my back."

"I couldn't feel my legs ... so we came back, and then as I got off the boat the woman said to me, 'You can't sue us: you signed a waiver'."

However, Lawyers at Slater and Gordon successfully argued the paperwork she signed wasn't clearly explained.

"They (the company involved) had to come to the party and acknowledge that we weren't informed enough of this waiver," Ms Bell says. 
While she's happy with the settlement, Ms Bell says she'll never be the same following her experience.

\begin{abstract}
“There are a lot of things I can't do: I can't vacuum or hang the clothes out without getting pain in my back, I can't lift anything over five kilos. It's just changed my life and I'll never get on a boat again."
\end{abstract}

"Make sure if you're going on anything like this to be careful of what you're signing and to ask a lot of questions."

The Linda Bell case is reported here just as it appeared in the news article. Contact with the lawyers representing Ms. Bell requesting a copy of the Statement of Claim filed for the case confirmed that this was not available due to the confidential settlement. Similarly, an approach to the Court Registry was unsuccessful for the same reason. Although the authors know of other cases involving whale watching injuries these are also protected by confidentiality agreements and legal privilege.

The situation is not unique to Australia. In the case of 3-year-old Ryker Hamilton, the boy who hit his head on a handrail and died during a whalewatching trip off Diamond Head, Hawaii in 2003, news of a settlement was reported on his lawyers' website (Vorsino, 2004). However, the statement also noted, "Rick Fried, attorney for the boy's family, said terms of the settlement would not be disclosed as part of the agreement."

The two Australian legal cases reported above involved injuries due to waves, a situation that is a very real risk for whale-watching tourism vessels worldwide as demonstrated in British Columbia with the 1998 swamping of Ocean Thunder (Proctor, 2015) and the sinking of the Leviathan II (Givetash, 2018). Disputes relating to waivers of liability and the adequacy of passenger briefings are also common concerns. For example, in the case of Ocean Thunder the coroner found that the passengers were given no instructions regarding the proper use of their "floater suits" nor were instructions given concerning boat or VHF operation (North, 1998).

\section{Vulnerability of Tourists}

It is well established that tourists on holidays tend to "leave their worries at home and assume someone else is looking after them." Sociologist and international tourism consultant Dr. Peter Tarlow refers to this as "a state of anomie" where international tourists, in particular, can become easily confused due to jet lag, unfamiliar activities and language barriers (Tarlow, 2006). Tourists often tend to be excited and focused only on what they are doing, not paying attention to safety issues unless these are specifically drawn to their attention.

A good example is safety signage at entrances to beaches. Research shows that visitors walk past prominent signage and, when later asked, they report that they did not notice the signage as they were totally focused on getting onto the beach (Matthews, Andronaco, \& Adams, 2014; Wilks, 2017). For this reason, there is no substitute for providing detailed safety briefings and direct supervision for tourists, especially international visitors (Wilks, Pendergast, \& Leggat, 2006; Wilks, 2008).

Business and government agencies publically acknowledge the importance of this responsibility. The Business Queensland (2018) website, for example, has a special section on Visitor Safety Advice for Tourism Operators. The website notes:

While Queensland is a friendly and safe place to travel, it does pose some real risks for tourists who are away from their home environment (e.g. tourists who aren't strong swimmers or who aren't fluent in English).

Engaging with your visitors directly - talking to them clearly about safety risks - reduces the likelihood of accidents and injuries, ensuring that they have a memorable and safe holiday experience.

\section{Maritime Safety Standards}

The minimum industry standard for all tourism operations is firstly compliance with relevant legislation. In Australia, the Marine Safety (Domestic Commercial Vessel) National Law Act 2012 (Cth) (2016) imposes safety obligations on owners and masters of vessels to "so far as is reasonably practicable" ensure the safety of their vessels, marine safety equipment that relates to the vessel and the operation of the vessel. To assist owners and masters in their obligations the Australian Maritime Safety Authority (AMSA), as the national regulator, has developed Guidelines for a Safety 
Management System (Australian Maritime Safety Authority, 2018).

The Safety Management System (SMS) notes that because Australian vessels operate in diverse circumstances and environments their safety systems "must be tailored to reflect the size, complexity and area of operation, as well as the risks unique to their vessel and operation" (p. 3). For all commercial vessels one of the minimum requirements is a Passenger Safety Briefing. The SMS provides a Passenger Safety Briefing Form that uses a whale watching Eco Tour as an example. The template covers a head count, weather and sea conditions, emergency procedures, and a life jacket demonstration by a member of the crew. Special passenger considerations on any trip, such as carrying seniors or passengers with restricted mobility, must also be addressed as part of the procedures for on board operations.

\section{Critical Importance of Safety Briefings}

Since 1998 Workplace Health and Safety Queensland has recognized the importance of providing safety information for international visitors, especially in the areas of scuba diving and snorkeling, and currently offers safety information handouts in 13 languages, including Simplified Chinese and Traditional Chinese (Workplace Health and Safety Queensland, 2017).

On their website Workplace Health and Safety Queensland (2017) notes that:

Many recreational dive and snorkelling participants do not speak English as their first language and may not understand the risks of the activities or the safety advice provided by the person conducting the business or undertaking (PCBU).

Some cultures may not appreciate aspects of water safety commonly known by most Australians and be at significant risk if not adequately equipped and supervised.

Generally using workers able to speak with the non-English speaking participants in their own language is the best way to allow two-way communication to occur. PCBUs who deal regularly with non-English speaking participants should try to ensure bilingual workers are available. Sometimes interpreters, such as bilingual tour guides, can assist.

\section{Conveying Safety Information}

Depending on the size of the tourism business and the nationalities of the overseas tourists they have as customers many marine tourism operators are now choosing to appoint their own interpreters. Other systems of conveying safety instructions include pictorial safety cards in relevant languages and videos that can be played to overseas tourists in the terminal or departure point prior to boarding a vessel. The advantage of a video in the visitor's own language is that all safety instructions are standardized and no important information is missed. It can also add visually to the excitement and anticipation of the tourism experience, while contextualizing safety as part of the activity.

Some companies require signed acknowledgement of the risks involved in the activity and this may provide some legal protection for operators if it is drawn to the attention of the customers and explained in a timely manner, but it does not necessarily improve operational safety. Early screening of customers at the time of the booking is more effective to ensure the elderly and those with mobility considerations are capable of comfortably enjoying the adventure experience offered. Early screening also avoids disappointment if someone has already paid for the trip, is looking forward to the experience and then at the last moment is denied boarding.

Lastly, tourism operators should be careful with the material on their websites, in brochures (e.g., Lormine Pty Ltd \& Anor v Xuereb in 2006) (Wilks, Atherton, \& Cavanagh, 1994) and in statements made to customers about safety issues (e.g., Rohra $v$ Ox Two Pty Ltd t/a Ocean Extreme, 2016, where the plaintiff was assured by staff as to the safety of the ride). The increasingly common practice of "promising" a whale sighting on every outing may also create unnecessary economic pressure on operators and compromise safety.

\section{Recommendations for Whale-Watching Operators}

The main causes of injuries identified in this review were the result of waves and associated violent vessel movement. Where there has been a failure to keep a proper lookout for waves and safely adapt to changing sea conditions the operators have 
been found negligent. Crew training and regular emergency practice drills are therefore essential to prepare for such situations. The Australian Maritime Safety Authority (2018) recommends that operators undertake a comprehensive risk assessment, develop a documented emergency plan, and ensure that the crew are sufficiently trained "so that they are fully aware and competent to safely perform their duties in relation to key on board operations and emergency plans" (p. 21). One of the critical questions in this area is "How rough does the sea have to be before operations will be stopped?"

The need to adequately prepare passengers is the second major finding of this review. Attending to procedures for on board operations is more effective than relying on Release of Liability or Waiver of Claims forms. The Australian Maritime Safety Authority (2018) recommends that the following questions be addressed:

- Where will passengers board and disembark?

- What will be completed before passengers are permitted to embark or disembark the vessel?

- How will passengers be briefed?

- How will you brief non-English-speaking passengers?

- When and where will the briefing take place, for example on the wharf or jetty before departure, on the vessel before or during departure?

- How will passengers be monitored?

To further assist operators the Guidelines for a Safety Management System include a Passenger Safety Briefing Form that uses whale watching as an example. The template covers a head count, weather and sea conditions, emergency procedures, and a life jacket demonstration by a member of the crew. Using these recommended measures will ensure that there is no inaccurate or misleading promotion and communication about the nature of the tour and associated risks, an issue that has been successfully raised against operators in the past (e.g., Lormine Pty Ltd \& Anor v Xuereb in 2006).

\section{Conclusion}

The Australian experiences described in this article have relevance for whale-watching vessels in other locations. The diversity of tourists engaging with whale watching has grown and, as a consequence, the languages, cultures, and most importantly familiarity with sea-based activities has also changed. Many whale watchers are unfamiliar with the sea and its unpredictability. In contrast, vessel operators and their crews are sea-faring people who are typically comfortable and relaxed on the water. Furthermore, they are instinctively familiar with such things as boat movement, balance, noise, variable weather conditions, sun, wind, and saltwater exposure and stomach reactions to sea state. This familiarity and experience can lead to a lack of understanding and empathy with passengers who often have a completely different background and are totally unfamiliar with the risks associated with being aboard a vessel at sea. As well as vessels meeting all maritime safety requirements in their jurisdictions it is imperative that whale-watching operators take the time to fully brief passengers on safety matters, including the use of personal floatation devices and emergency procedures, in a way that they fully understand. If this is done in a sensitive and appropriate way safety can become an important part of the whale watching adventure both reassuring tourists and improving safety outcomes.

\section{Biographical Notes}

Dr. Jeff Wilks is a consulting psychologist and qualified lawyer specializing in travel health, safety, and well-being. Trained in social and cross-cultural psychology Jeff has led risk management programs for the United Nations and industry groups in the Middle East, the UK and the US, as well as closer to home in Asia Pacific. He is widely published in travel medicine, tourism, and travel law.

Michael Lück is a professor in the School of Hospitality and Tourism, Auckland University of Technology, New Zealand. Michael has more than 10 years' work experience in the tourism industry and his research interests include (marine) wildlife tourism, the cruise industry, ecotourism, interpretation and education on wildlife tours, the impacts of tourism, and aviation. He has published in a number of international journals, is founding Editor-in-Chief of Tourism in Marine Environments, and is on the editorial boards of the Journal of Ecotourism and Marine Policy and Frontiers. Michael has edited or coedited more than 10 books, including the Encyclopedia of Tourism and Recreation in Marine Environments (CABI).

Professor Mark Orams is currently Interim Dean of the Faculty of Health and Environmental Sciences at the Auckland 
University of Technology, Aotearoa/New Zealand. His academic career has focused on marine recreation, sport, and tourism and follows a lifetime of playing, exploring, and adventuring on the ocean.

\section{ORCID}

Jeff Wilks: (iD https://orcid.org/0000-0003-3553-0039

Michael Lück: (iD https://orcid.org/0000-0002-6473-8579

Mark Orams: (D https://orcid.org/0000-0001-6806-7891

\section{References}

Addley, E., \& Morrow, F. (2015, October 27). Five Britons die after whale-watching boat sinks off Canadian coast. The Guardian. Retrieved from https:// www.theguardian.com/world/2015/oct/26/fivebritons-die-whale-watching-boat-sinks-canada

Al-Thani, H., El-Menyar, A., Mekkodathil, A., \& Abdelrahman, H. (2017). Types, patterns and outcomes of personal watercraft-related trauma. Annals of Medical and Health Sciences Research, 7(1), 39-43.

Andersen, M. S., \& Miller, M. L. (2006). Onboard marine environmental education: Whale watching in the San Juan Islands, Washington. Tourism in Marine Environments, 2(2), 111-118.

Associated Press. (2015, March 31). Whale slams into boat, killing tourist. New York Post. Retrieved from https://nypost.com/2015/03/13/whale-slams-into-boatkilling-tourist/

ABC News. (2019, July 8). Boat collides with whale near Geraldton, injuring fisherman and damaging craft. Retrieved from https://www.abc.net.au/news/2019-07-08/ man-injured-in-wa-whale-collision/11287168

Australian Maritime Safety Authority. (2018). Guidelines for a safety management system. Retrieved from https:// www.amsa.gov.au/sites/default/files/amsa610-guidelines-for-a-safety-management-system-august2018.pdf

Baker, P. (2017, September 7). 'A terrible nightmare': B.C. man left a paraplegic after boat collides with humpback in Haida Gwaii. Global News. Retrieved from https://globalnews.ca/ news/3718683/a-terrible-nightmare-b-c-man-left-a-paraplegic-after-boat-collides-with-humpback-in-haida-gwaii/

BBC News. (2019, March 9). Japan ferry 'hits whale', injuring more than 80 on board. Retrieved from https://www. bbc.com/news/world-asia-47509017

Bentz, J., Lopes, F., Calado, H., \& Dearden, P. (2016). Enhancing satisfaction and sustainable management: Whale watching in the Azores. Tourism Management, 54, 465-476.

Brand South Africa. (2009). South Africa to market the 'Big Seven'. Retrieved from https://www.brandsouthafrica. com/governance/sustainable/big7-220609

Business Queensland. (2018). Visitor safety advice for tourism operators. Retrieved from https://www.business. qld.gov.au/industries/hospitality-tourism-sport/tourism/ running/customer-service/visitor-safety
Carlson, C. (2012). A review of whale watch guidelines and regulations around the world. Retrieved from https:// us.whales.org/wp-content/uploads/sites/2/2018/08/ whale-watching-guidelines-review-2008.pdf

Carlson, C., Rose, N., Kato, H., \& Williams, R. (2014). The International Whaling Commission (IWC) and whalewatching. In J. Higham, L. Bejder, \& R. Williams (Eds.), Whale-watching: Sustainable tourism and ecological management (pp. 71-78). Cambridge, UK: Cambridge University Press.

CBS News. (2014, July 3). Blue whale capsizes boat off San Diego. Retrieved from https:/www.cbsnews.com/news/ blue-whale-capsizes-boat-off-san-diego/

Cisneros-Montemayor, A. M., Sumaila, U. R., Kaschner, K., \& Pauly, D. (2010). The global potential for whale watching. Marine Policy, 34, 1273-1278.

Conrad, C., \& Larson, A. (2018, October 4). Two boats collide with whales in Monterey Bay. KSBW8 News. Retrieved from https://www.ksbw.com/article/two-boatscollide-with-whales-in-monterey-bay/23585828

Cooper, N. (2016). Whale watching brings more than half a million tourists to Queensland. Retrieved from https:// www.brisbanetimes.com.au/national/queensland/whalewatching-brings-more-than-half-a-million-tourists-toqueensland-20160622-gpplbp.html

Cote, C. (2017). Coroner's report into the death of Jack Slater. Case No. 2015-1031-0036. Ministry for Public Safety and Solicitor General British Columbia. Retrieved from https://www2.gov.bc.ca/assets/gov/birth-adoptiondeath-marriage-and-divorce/deaths/coroners-service/ news/2018/cr_jackslater_2015_1031_0036.pdf

Department of Environment and Energy. (2017). Australian national guidelines for whale and dolphin watching. Canberra, Australia: Commonwealth of Australia.

Department of Environment and Science. (2018). Commercial interaction with protected animals. Brisbane: Queensland Government. Retrieved from https://www. ehp.qld.gov.au/licences-permits/plants-animals/commercial-use-animals/commercial_interaction_with_protected_animals.html\#permits_and__approvals

DePledge, D. (2003, December 26). Boy dies on whale cruise. Honolulu Advertiser. Retrieved from http://the. honoluluadvertiser.com/article/2003/Dec/26/ln/ln04a. html

European Child Safety Alliance. (2007). Tourism and water-related injuries. Retrieved from https://www. childsafetyeurope.org/publications/info/factsheets/tourism-water-related-injuries.pdf

Farrell, P., \& Evershed, N. (2014, June 27). Revealed: Whale-watching boats the greatest collision threat to whales. The Guardian. Retrieved from https://www. theguardian.com/news/datablog/2014/jun/27/-sp-whalewatching-boats-pose-greatest-threat-to-whales

Finkler, W., \& Higham, J. (2004). The human dimensions of whale watching: An analysis based on viewing platforms. Human Dimensions of Wildlife, 9(2), 103-117.

Givetash, L. (2018, February 6). Coroner rules deaths of 6 in Tofino whale-watching tragedy as accidental. CBC 
News. Retrieved from https://www.cbc.ca/news/canada/ british-columbia/tofino-whale-watching-ship-sinkingleviathan-ii-coroners-report-1.4523190

Higham, J., Bejder, L., \& Williams, R. (Eds.). (2014). Whalewatching: Sustainable tourism and ecological management. Cambridge, UK: Cambridge University Press.

Higham, J. E., \& Lück, M. (Eds.). (2007). Marine wildlife and tourism management: Insights from the natural and social sciences. Wallingford, UK: CABI.

Hoyt, E. (2001). Whale watching 2001: Worldwide tourism numbers, expenditures and expanding socioeconomic benefits. Yarmouth, MA: International Fund for Animal Welfare.

Inquirer. (2011, June 20). Two injured as whale hits boat in Australia. Retrieved from https://newsinfo.inquirer. net/16515/two-injured-as-whale-hits-boat-in-australia

International Whaling Commission. (2019). Whale watching. Retrieved from https://iwc.int/whalewatching

Janjevic, D. (2017, 7 August). Whale slams into tourist boat off Australia. DW Media. Retrieved from https://www.dw.com/ en/whale-slams-into-tourist-boat-off-australia/a-39988625

Jasper, R., Stewart, B. A., \& Knight, A. (2017). Behaviours and attitudes of recreational fishers toward safety at a 'blackspot' for fishing fatalities in Western Australia. Health Promotion Journal of Australia, 28(2), 156-159.

Knowles, T., \& Campbell, R. (2011). What's a whale worth? Valuing whales for National Whale Day. Melbourne, Australia: International Fund for Animal Welfare (IFAW) $\&$ Economists at Large.

Lawrence, J. (2017, August 8).Two injured after whalewatching vessel strikes humpback near Victoria. CTV News Vancouver Island. Retrieved from https://vancouverisland.ctvnews.ca/two-injured-after-whale-watchingvessel-strikes-humpback-near-victoria-1.3537747

Lindsey, P. A., Alexander, R., Mills, M. G. L., Romañach, S., \& Woodroffe, R. (2007). Wildlife viewing preferences of visitors to protected areas in South Africa: Implications for the role of ecotourism in conservation. Journal of Ecotourism, 6(1), 19-33.

Lois, P., Wang, J., Wall, A., \& Ruxton, T. (2004). Formal safety assessment of cruise ships. Tourism Management, 25(1), 93-109.

Lück, M. (2003). Education on marine mammal tours as agent for conservation-But do tourists want to be educated? Ocean \& Coastal Management, 46(9-10), 943-956.

Lück, M. (2015). Education on marine mammal tours-But what do tourists want to learn? Ocean \& Coastal Management, 103, 25-33.

Lum, C., \& Gordon, M. (2003, December 27). Accounts differ on death of boy, 3 , in whale-watch boat. The Honolulu Advertiser. Retrieved from http://the.honoluluadvertiser. com/article/2003/Dec/27/ln/ln01a.html

Marine Safety (Domestic Commercial Vessel) National Law Act 2012 (Cth). (2016). Retrieved from https://www.legislation.gov.au/Details/C2016C00377

Matthews, B., Andronaco, R., \& Adams, A. (2014). Warning signs at beaches: Do they work? Safety Science, 62, 312-318.
Nielsen. (2017). Outbound Chinese tourism and consumption trends. Retrieved from https://www.slideshare.net/digital inasia/outbound-chinese-tourism-and-consumption-trends

Newsome, D., Dowling, R. K., \& Moore, S. A. (2005). Wildlife tourism. Clevedon, UK: Channel View Publications.

North, P. (1998). Judgement of Inquiry into the Death of Stephen Reimers. Case No. 98-126-0001. Ministry of Attorney General, B.C. Coroner's Service. Retrieved from https://www.documentcloud.org/documents/2488614whale-watching-cr.html

O'Connor, S., Campbell, R., Cortez, H., \& Knowles, T. (2009). Whale watching worldwide: Tourism numbers, expenditures and expanding economic benefits. Yarmouth, MA: International Fund for Animal Welfare.

Orams, M. (2000). Tourists getting close to whales, is it what whale-watching is all about? Tourism Management, 21(6), 561-569.

Orams, M., Forestell, P., \& Spring, J. (2014). What's in it for the whales? Exploring the potential contribution of environmental interpretation to conservation In J. Higham, L. Bejder \& R. Williams (Eds.), Whale-watching: Sustainable tourism and ecological management (pp. 146-162). Cambridge, UK: Cambridge University Press.

ORC International. (2014). Chinese satisfaction survey. Summary report. Canberra, Australia: Tourism Research Australia.

Parsons, E. C. M. (2012). The negative impacts of whalewatching. Journal of Marine Biology, 2012, 807294. doi: http://dx.doi.org/10.1155/2012/807294

Proctor, J. (2015, October 27). 1998 Tofino whale-watching accident sparked call for regulation. CBC News. Retrieved from https://www.cbc.ca/news/canada/british-columbia/1998-tofino-whale-watching-accidentsparked-call-for-regulation-1.3289760

Queensland Marine Parks. (2017). Marine park permits and activities. Retrieved from https://www.qld.gov.au/ environment/coasts-waterways/marine-parks/permits

Reid, E., \& Perets, A. (2018, August 26). LISTEN: Man stranded in ocean after boat hits whale and sinks. News Mail. Retrieved from https://www.news-mail.com.au/ news/night-rescue-man-left-floating-after-whale-hitsbo/3503634/

Rohra v Ox Two Pty Ltd (t/a Ocean Extreme) [2016] NSWDC 78/BC201640119.

Stanton, K. (2013, May 18). Terrifying humpback whale encounter leaves B.C. boater injured. Global News. Retrieved from https://globalnews.ca/news/574317/warning-for-boaters-to-keep-an-eye-out-for-humpback-whalesafter-an-accident-in-b-c-waters/

Steven, R., Morrison, C., \& Castley, J. G. (2015). Birdwatching and avitourism: A global review of research into its participant markets, distribution and impacts, highlighting future research priorities to inform sustainable avitourism management. Journal of Sustainable Tourism, 23(8-9), 1257-1276.

Talley, W. K. (2002). The safety of ferries: An accident injury perspective. Maritime Policy \& Management, 29(3), 331-338. 
Talwar v Ox Two Pty Ltd (t/a Ocean Extreme) [2017] NSWDC 72/BC201740176.

Tarlow, P. (2006). Crime and tourism. In J. Wilks, D. Pendergast, \& P. Leggat (Eds.), Tourism in turbulent times: Towards safe experiences for visitors (pp. 93-105). Oxford, UK: Elsevier.

Tourism \& Events Queensland. (2018). Unpacking the Chinese leisure traveller. Retrieved from https://cdn2-teq. queensland.com/ /media/0555a68b20854775b97f272e 6669d12b.ashx?la=en-au\&vs=1\&d=20180703T134556

Transportation Safety Board of Canada. (1998). Marine investigation report. Swamping with loss of lives. Whalewatching passenger boat "Ocean Thunder" off Tofino, British Columbia, 22 March 1998. Retrieved from http://www.tsb.gc.ca/eng/rapports-reports/marine/1998/ m98w0045/m98w0045.pdf

Tripleem News. (2018). Hamlyn Terrace woman compensated for whale watching injury. Broke her back. Retrieved from https://www.triplem.com.au/news/central-coast/ hamlyn-terrace-woman-compensated-for-whale-watching-injury?station=frasercoast

Vorsino, M. (2004). 3 year old's death leads to settlement. The whale-watching company will make changes to prevent future accidents. Retrieved from https://www. croninfried.com/In-The-News/3-year-olds-death-leadsto-settlement.shtml

Wilks, J. (2000). Scuba diving and snorkelling safety on Australia's Great Barrier Reef. Journal of Travel Medicine, 7, 283-289.

Wilks, J. (2007). Tourist scuba diving deaths: Australian evidence. International Travel Law Journal, 14(4), 238-251.

Wilks, J. (2008). Considering the standard of care for tourists. International Travel Law Journal, 15(3), 135-142.
Wilks, J. (2010). Jet ski accidents. Travel Law Quarterly, 2 , 229-232.

Wilks, J. (2012). Balancing tourism and safety: The case of jet skis. Travel Law Quarterly, 4, 113-116.

Wilks, J. (2017). Tourism and aquatic safety: No lifeguard on duty-Swim at your own risk. Tourism in Marine Environments, 12(3-4), 211-219.

Wilks, J., Atherton, T., \& Cavanagh, P. (1994). Adventure tourism brochures: An analysis of legal content. Australian Journal of Hospitality Management, 1, 47-53.

Wilks, J., \& Davis, R. (2000). Risk management for scuba diving operators on Australia's Great Barrier Reef. Tourism Management, 21, 591-599.

Wilks, J., \& Page, S. J. (2003). Current status of tourist health and safety. In J. Wilks \& S. J. Page (Eds.), Managing tourist health and safety in the new millennium (pp. 3-15). Oxford, UK: Elsevier.

Wilks, J., Pendergast, D., \& Leggat, P. (Eds.). (2006). Tourism in turbulent times: Towards safe experiences for visitors. Oxford, UK: Elsevier.

Wilson, C., \& Tisdell, C. (2003). Conservation and economic benefits of wildlife-based marine tourism: Sea turtles and whales as case studies. Human Dimensions of Wildlife, 8(1), 49-58.

Workplace Health and Safety Queensland. (2017). NonEnglish speaking participants. Retrieved from https:// www.worksafe.qld.gov.au/diving-snorkelling/divingand-snorkelling-hazards/non-english-speakingparticipants

Zeppel, H., \& Muloin, S. (2008). Conservation benefits of interpretation on marine wildlife tours. Human Dimensions of Wildlife, 13(4), 280-294. 
Copyright of Tourism in Marine Environments is the property of Cognizant, LLC and its content may not be copied or emailed to multiple sites or posted to a listserv without the copyright holder's express written permission. However, users may print, download, or email articles for individual use. 